\title{
How Significantly for Emerging Economies to Benefit From Board Attributes and Risk Management in Enhancing Firm Profitability?
}

Tariq Tawfeeq Yousif Alabdullah ${ }^{1}$, Essia Ries Ahmed ${ }^{2}$, Mohammed Almashhadani ${ }^{3}$, Sara Kadhim Yousif ${ }^{4}$, Hasan Ahmed Almashhadani ${ }^{5}$, Raghad Almashhadani ${ }^{6}$, Eskasari Putri ${ }^{7}$

1 Accounting Department, College of Administration and Economics, University of Basrah, Iraq, ${ }^{2}$ Collage of Economics, Management and Information Systems, University of Nizwa, Oman, 3,5,6 University of Houston, USA,'

${ }^{4}$ University of Basrah, Iraq, ${ }^{7}$ Faculty of Economics and Business, Universitas Muhammadiyah Surakarta, Indonesia.

\section{OPEN ACCESS}

ISSN 2548-3501 (online)

Edited by:

Eny Maryanti

Reviewed by:

Dr. Basel J. A. AL

${ }^{*}$ Correspondence

Tariq Tawfeeq Yousif Alabdullah tariqtariq1984@gmail.com

Received: 5 April 2021 Accepted: 05July 2021

Published: 31 July 2021

Citation:

Alabdullah TTY AhmedER,

Almashhadani M, YousifS $k$,

Almashhadani HA, Almashhadan

$R$, and Putri E (2021) How

significantly to emerging economies

benefitfrom board attributes and

risk management in enhancing firm
This paper aims to considerably contribute to the area of corporate governance to be then involved in the new trends testing the role of board attributes as mechanisms of corporate governance to know whether non-financial companies in the developing economies will benefit from these mechanisms in their impact on firm profitability. Thus, the present study tested 100 non-financial companies based on their annual reports in the year of 2020 as a cross-sectional study. The results of testing the variables of the current study revealed that there is a negative link between board of directors size and profitability. On the other hand, the results showed that the managers independency has no relationship with profitability. Likewise, the results revealed that risk management has no effect on profitability.

Keywords: Board attributes, Risk management, Firm profitability, Developing Economies

Artikel ini bertujuan untuk memberikan kontribusi besar pada bidang tata kelola perusahaan untuk kemudian terlibat dalam tren baru yang menguji peran atribut dewan sebagai mekanisme tata kelola perusahaan untuk mengetahui apakah perusahaan non-keuangan di negara berkembang akan mendapat manfaat dari mekanisme ini dalam dampaknya. dari profitabilitas perusahaan. Dengan demikian, penelitian ini menguji 100 perusahaan non-keuangan berdasarkan laporan tahunan mereka di tahun 2020 sebagai studi cross sectional. Hasil pengujian variabel penelitian ini mengungkapkan bahwa ada hubungan negatif antara ukuran dewan direksi dan profitabilitas. Di sisi lain, hasil penelitian menunjukkan bahwa independensi manajer tidak memiliki hubungan dengan profitabilitas. Demikian juga, hasil penelitian mengungkapkan bahwa manajemen risiko tidak berpengaruh terhadap profitabilitas.

Kata Kunci: Atribut Dewan, Manajemen Risiko, Profitabilitas Perusahaan, Ekonomi Berkembang 


\section{INTRODUCTION}

It is known through researches done in the whole world that corporate governance (CG) is known as a great instrument in assessing the firms' ability of being functional and strong ((Alabdullah, Yahya \& Ramayah, 2014; Alabdullah, et al., 2014; Alfadhl et al, 2013; Alfadhl and Alabdullah, 2016; Crifo, Escrig-Olmedo, \& Mottis, 2019). $\mathrm{CG}$, together with its mechanisms and structures is very useful to monitor profitability of the firm (Alabdullah 2019). The best CG reflects better information to make the firm reach its targets and goals; that's to reach the effective level of firm profitability (Alabdullah, 2018). This made CG strongly appear in the last few decades in several developed and developing countries. This system appeared before a hundred years but in another form as controlling role that has standards, principles and mechanisms that help differen parties (e.g., Alabdullah, 2019; Ahmed, Alabdullah et al. 2020; Alabdullah, 2018; Alabdullah, 2016a, 2016b, 2016c 2016d, 2017, 2018; Alabdullah , Laadjal, Ries, \& Al-Asadi, 2018). Its mechanisms are board size, board independency, duality, gender, and ownership structure plus other internal mechanisms .

In spite of the reality that $\mathrm{CG}$ is a systematic controlling system that is characterized by its precise mechanisms and principles, yet there is no unified definition that expresses the concept of CG (Alabdullah, 2019; Alabdullah et al., 2014; Brickley \& Zimmerman, 2010). Accordingly, there is a diversity of meanings for CG that appeared in the literature. For example, CG is considered as a control system to control and concentrate on a firm (Cadbury Report, 1992). Alabdullah et al., (2019) demonstrated that $\mathrm{CG}$ is also related to the link between owners and agent. They focus on the important case of CG in limiting the probable struggle between these two main parties. In line with such studies, Alabdullah, Ries, \& Thottoli, (2019) and Solomon \& Solomon, (2008) and Alabdullah, et al., (2018) declare that most of academics and researchers are in line with the fundamental notion that CG regulates principles and control mechanisms that aim to make the managers in the companies perform in the best attention of shareholders. As (Bai et al., 2004; Rechner \& Dalton, 1989; Yermack, 1996; Zheka, 2006) reveal, CG is the link among shareholders utilized to recognize and oversee company's performance.

In the 19th century specifically, as explained by (Alabdullah, 2020; Alabdullah, Yahya \& Ramayah, 2014b) there was the obvious start for knowing corporate governance $(\mathrm{CG})$. The known problem is that there is a conflict and gap between managers in the companies and their owners, and as a conclusion there will be undesirable work by the management's directors that may damage the company as mentioned by (Alabdullah, 2020; Alabdullah, et al., 2019; Alabdullah, Ries, \& Thottoli, 2019; Alabdullah, et al., 2018; Alabdullah, et al., 2018; Alabdullah, et al., 2016; Alabdullah, Yahya, \& Ramayah, 2014b). Therefore, CG notion emerged to detect relations linked to the board, management branch directors as well as the managers independency, board size, and risk management in the firms and also to link shareholders and other heedful parties. Lastly CG is presently the core mandate for the directors and their work in whole world especially while suffering from a multi-directional pandemic and its serious impacts on the economy, and social and environmental situations (Alabdullah, et al., 2020). Bad practices of CG are a result of poor firm's profitability and consequently may increase the negative impact of the global crises and might increase the fraud and manipulations Hebble \& Ramaswamy, 2005;
Brennan \& Solomon, 2008).

Several studies such as Widiatmika and Darma, (2018) admitted that there is a kind of absence in testing deferent variables of good corporate governance that probably have an impact on the company's profitability. There is a concern in the previous studies towards good practices of $\mathrm{CG}$ in the last years in emerging economies (e.g., Alabdullah, 2016a, 2016b, 2016c, 2017, 2018, 2020; Alabdullah , Laadjal, Ries, \& Al-Asadi, 2018; Alabdullah, Ries, , \& Nor, 2019; Alabdullah, Ries, \& Thottoli, 2019; Alabdullah, Nor, \& Ries, 2018; Alabdullah, Yahya, Nor, \& Majeed, 2016; Alabdullah et al., 2014;Alabdullah, et al, 2021), whereas there is a dire requisite for offering further considerations to focus on new contributions in testing new variables. As for Jordan as a context of the present work, depending on contemporary studies, the non-financial firms in Jordan have several problems which represent serious challenges in several matters in companies listed in Amman Stock Exchange (ASE). For instance (Mensi, Tiwari \& Yoon, 2017; Ahmed et al., 2020; Ahmed, Amran, \& Islam, 2018; Ahmed, et al., 2018; Ahmed et al., 2019; Ahmed \& Aumran, 2019; Ahmed, Islam, \& Amran, 2019; Asmild et al., 2019; Ahmed et al., 2018; Ahmed, Islam, Zuqibeh, \& Alabdullah, 2014; Ahmed, Islam, \& Alabdullah, 2014) confirmed there is a deficiency in the skills of management and in the achievements of technology towards new trends in several Jordanian listed companies. They suggested that there is distinguished problems and challenges faced by Jordanian non-financial companies that require serious intervention by academics, scholars and researchers.

The problems illustrated above characterize a call for academics and scholars to increase attention to the Jordanian companies and the need of looking for matters that help improve companies' profitability in Jordanian nonfinancial companies as this enhancement eventually will be a reason to achieve good economic profitability of the country as a result. Accordingly, this work is considered to be a response to what was deliberated in prior works; thus it targets at investigating the relation between $\mathrm{CG}$ and companies' profitability in Amman stock Exchange (ASE) in Jordan.

The relationship between $\mathrm{CG}$ and profitability is also investigated by Kivaya, Kemboi and Odunga, (2020) in SMEs companies in Nairobi via testing the impact of board size and CEO duality as a moderator in this relation and the results mentioned that there is a negative impact on profitability of such companies. Bahoo, Ahmed, Shoukat and Ahmad, (2019) investigated the link between managerial ownership and corporate governance and the impact of this relationship on firm profitability and they found that $\mathrm{CG}$ has notable influence via financial profitability on firm profitability. $C G$ and sustainability have been tested by other studies. For example, Munir, Khan, Usman and Khuram, (2019) found that the good CG system enhances profitability and sustainability; in the long term also it will enhance firm value. CG and intellectual capital were investigated by Susanti, Andhani and Zulaihati, (2019) and they found that there is a positive link between them. Also another study done by Haq, Zhao, and Rehman, (2020) utilized several variables like independency and board size to test their impact on profitability and the findings were positive.

Jamel, Albogami, Abdulaal, and Aljohani, (2021) tested the effect of agency conflicts between directors and stockholders on firm risk management and financial profitability of Saudi listed companies. The results reveal that risk management rises the corporate risk management and the profitability of Saudi company. Rangkuti, (2020) tests the impact of Tier-1 capital 
on risk management and Indonesian banks' firm performance. They show that Tier-1 capital positively affects risk management, Tier-1 capital also has a significant impact on firm financial performance with its link to risk management as a mediation predictor. The findings show that there is a positive effect of risk management on firm financial performance.

Based on the above, we predict the following hypotheses: $\mathrm{H} 1$. There is a negative link between size of the board of directors and profitability.

$\mathrm{H} 2$. There is a positive link between managers independency and profitability.

$\mathrm{H} 3$. There is a positive link between risk management and profitability.

\section{METHOD}

The present work covered companies listed in ASE for 100 companies for the year 2020 as a secondary data and crosssectional study. Accounting data was collected for all variables of the current work; independent and dependent variables. The variables are represented by growth as the dependent variable to reflect the profitability of the company and for the independent variables, we utilized board size, managers independency and risk management as corporate governance mechanisms.

\section{RESULTS AND DISCUSSION}

In this work, we used multiple regression to recognize the direct link between independent and dependent variable. As explained in Table 1, the Multicollinearity test revealed that the tolerance for the independent variables of the current study were: 0.855 for the board size; 0.8 .92 for managers independency; and 0.944 for risk management. This indicates that there is no problem of Multicollinearity since the value of tolerance is more than 0.1 of all the independent variables. The findings reveal that the value of $\mathrm{R}$ square is 0.905 for the growth as shown in Table 2. This indicates that this value explains $90 \%$ of the independent variables (board size, managers independency and risk management) on the dependent variable which is growth.

[Table 1 about here.]

\section{[Table 2 about here.]}

After the analysis of the multiple regression, as shown in Table 3 , which applies to all variables, it shows that the link between board size and profitability represented by company growth was negative $(\beta=-.917)$ and for the risk management was also negative with the value of $(\beta=-.018)$, while the managers' independency was positive with profitability $(\beta=0.027)$.

The investigating hypotheses of this work revealed surprising findings about the link between independent and dependent variables. There is a high negative and significant effect between board size and companies' profitability at $\mathrm{P}<0.00$, $\beta=-$

917.

[Table 3 about here.]

Thus, H1 is considered as unsupported hypothesis and such findings expressed that small board size is active in listed companies in Jordan. Such a result reflects that it seems that in Jordanian non-financial companies the small board is a positive situation in enhancing firm profitability to be as such in line with the notion of agency theory which admits that small board size has its notable impact on firm profitability.

For hypothesis two, as predicted by the current study, there is a positive link between managers independency and profitability. The probable reason of such findings is that this factor is not an issue in the companies listed in Amman Stock Exchange. This reflects the notion that managers independency might be useful and might be not in this context. This work expected that risk management has a positive link with firm profitability. The findings are insignificant with $\mathrm{P}<$ $0.1, \beta=.034)$.

\section{CONCLUSION}

Corporate governance (CG) is extremely important system because the company is like a vehicle by which the majority of economy produces most of its services and goods and therefore how it is governed is definitely essential for the investors in the company that already work in the company and for the executives and eventually for the society as a whole. Therefore, it is very important for all sectors ; financial and non-financial ones. It is very important to realize how companies are owned in the developed countries and those that are owned in the developing countries. Nonetheless, in general, we need to control and apply new links with profitability in most companies. There are poor results by several studies that have not tried to link corporate governance to future growth from new perspectives as the current work has done so. Therefore, we need to have influence and new mechanisms that have positive impact on firm profitability. Thus, we see indeed that the variables of the current work are structured in a different way then we all think they should be structured.

This study revealed that more independency of managers in the board, having risk management committee in the firm, and small board size lead to promote firm profitability, that is linked to what has been argued by agency theory to control conflicts via its explanation of the relationship between the three independent variables of the current study and their relationship with firm profitability. Our results admitted that there is a negative impact of the small board size on profitability in listed companies in Jordanian context. In addition, its results regarding risk management showed that there is a significant positive influence on firm profitability.

The results add to the argument about the need for testing new link among the existing variables that were tested by the previous studies but have lost the contribution to the area of corporate governance. Also it showed that independency of the managers in Jordanian companies has an insignificant link. This means that this variable is considered as a very important issue and it does matter in this context.

The limitation of this study is that it did analysis just to the non financial listed firms in Jordan and did not take into account the financial sector. Therefore, for future studies, they should test whether or not that the findings will be the same as ours because CG effectiveness is similar in all countries around the world particularly between developed and developing economies.

\section{REFERENCES}

Ahmed, E. R., Alabdullah, T. T. Y., Ardhani, L., \& Putri, E. (2021). The Inventory Control System's Weaknesses Based on the Accounting Postgraduate Students' Perspectives. Journal of Accounting and Business 
Education, 5(2), 18.DOI:http://dx.doi.org/10.26675/jabe.v5i2.19312.

Ahmed, E. R., Abdul Rahim, N. F., Alabdullah, T. T. Y \& Thottoli, M. M. (2019). An Examination of Social Media Role in Entrepreneurial Intention among Accounting Students: A SEM Study. Journal of Modern Accounting and Auditing, 15(12).

Ahmed, E. R., Aiffin, K. H. B., Alabdullah, T. T. Y., \& Zuqubah, A. (2016). Zakat and Accounting Valuation Model. Journal of Reviews on Global Economics, 5, 16-24.

Ahmed, E. R., Alabdullah, T. T. Y \& Shaharudin, M. S. (2020). Approaches to Control Mechanisms and Their Implications for Companies' Profitability: a Study in UAE. Journal of accounting Science, Vol. 4, no. 2, pp. 11-20. Control, 13(4), 279-286.

Alabdullah, T. T. Y., Ahmed, E. R., \& Ahmed, R. R. (2021). Organization features and profitability: Implications for a sample of Emerging Countries. Journal of Accounting and Business Education, $\quad 5(2)$, 43- $52 . \mathrm{DOI}:$ http://dx.doi.org/10.26675/jabe.v5i2.16351.

Alabdullah, T. T. Y., Ahmed, E. R. (2019). Board Diversity and Disclosure of Corporate Social Responsibility Link: A Study in Malaysia. Journal of $A d v$ Research in Dynamic \&

Ahmed, E. R., Alabdullah, T. T. Y., Thottoli, M. M., \& Maryanti, Control System, 11(11). E. (2020). Does Corporate Governance Predict FirmAlabdullah, T. T. Y., Ahmed, E. R., \& Muneerali, M. (2019). Profitability? An Empirical Study in Oman. The International Journal of Accounting and Business Society, 28(1), 127-143.

Ahmed, E. R., Alabdullah, T. Y., Islam, M. A., \& Asmar, M. Effect of Board Size and Duality on Corporate Social Responsibility: What has Improved in Corporate Governance in Asia?. Journal of Accounting Science, 3(2), 121-135. (2014) "Sukuk Legitimacy: A New Measurement Based on Content Analysis" 16th Malaysian Finance Association Conference in Sasana Kijang Central Bank of Malaysia, Kuala Lumpur, June 4-6, 2014.

Ahmed, E. R., Islam, M. A., and Alabdullah, T. T. Y. (2018). The moderating role of Shariah supervisory board on sukuk pricing benchmark. International Journal of Excellence in Islamic Banking and Finance 6.

Ahmed, E. R., Islam, M. A., Alabdullah, T. T. Y., \& bin Amran, A. (2018). Proposed the pricing model as an alternative Islamic benchmark. Benchmarking: An International Journal, Vol. 25 No. 8, pp. 2892-2912.

Ahmed, E. R., Islam, M. A., Alabdullah, T. T. Y., \& Amran, A.B. (2019). A qualitative analysis on the determinants of legitimacy of sukuk. Journal of Islamic Accounting and Business Research, Vol. 10 No. 3, pp. 342-368.

Ahmed, E. R., Islam, A., \& Amran, A. B. (2019). Examining the legitimacy of Sukuk structure via Shariah pronouncements. Journal of Islamic Marketing, Vol. 10 No. 4, pp. 1151-1166.

Ahmed, E. R., Islam, M. A., \& Alabdullah, T. T. Y. (2014). Islamic sukuk: Pricing mechanism and rating. Journal of Asian Scientific Research, 4(11), 640.

Ahmed, E. R., Islam, A., Zuqibeh, A., \& Alabdullah, T. T. Y. (2014). Risks management in Islamic financial instruments. Advances in Environmental Biology, 402-406.

Ahmed, E. R., Alabdullah, T. T. Y., Shaharudin, M. S., \& Putri, E. (2020). Further Evidence on the Link between Firm's Control Mechanisms and Firm Financial Performance: Sultanate of Oman. Journal of Governance and Integrity, 4(1), 1-6.
Ahmed, E. R., Alabdullah, T. T. Y., Amran, A., \& Yahya, S. B. (2018). Indebtedness Theory and Shariah Boards: $A$ Theoretical Approach. Global Business and Management Research, 10(1), 127-134.

Alabdullah, T. T. Y. (2019). Management Accounting and Service Companies' Performance: Research in Emerging Economies, Australasian Accounting, Business and Finance Journal, 13(4), 2019, 100-118. doi:10.14453/aabfj.v13i4.8.

Alabdullah, T. T. Y. (2016a). Agency Theory Perspective: A Quantitative Study Of Accounting Performance Measures In Emerging Economies. ICTE Proceedings, New York.

Alabdullah, T. T. Y. (2016b). Are Board Size And Ownership Structure Beneficial In Emerging Markets' Firms? Evidence from Jordan. International Journal of Management \& Information Systems (IJMIS), 20(3), 87-94.

Alabdullah, T. T. Y. (2016c). Corporate Governance from The Perspective of The Past and The Present and The Need to Fill an International Gap. Risk Governance \& Control: Financial Markets \& Institutions, 6(4).

Alabdullah, T. T. Y. (2016d). The Performance of Companies and The Board's Characteristics From the New Perspective of Manipulation Avoidance. Corporate Ownership \&

Alabdullah, T. T. Y. (2018). The relationship between ownership structure and firm financial performance. Benchmarking: An International Journal, 25(1), 319-333.

Alabdullah, T. T. Y. (2017). Compensation committee, company board attributes, and company performance: The moderating effect of leadership position. Paper presented at the 2017 Wei International Academic Conference Proceedings, July 24-27, 2017, Business and Economics.

Alabdullah, T. T. Y., Alfadhl, M. M. A., Yahya, S., \& Rabi, A. M. A. (2014). The Role of Forensic Accounting in Reducing Financial Corruption: A Study in Iraq. International Journal of Business and Management, 9 (1), 26.

Alabdullah, T. T. Y., Laadjal, A., Ries, E., \& Al-Asadi, Y. A.A. (2018). Board Features and Capital Structure in Emerging Markets. Journal of Advanced Management Science, 6 (2).

Alabdullah, T. T. Y., Nor, M. I., \& Ahmed, E. R. (2018). The determination of firm performance in emerging nations: Do board size and firm size matter? Management, 5(3), 57-66.

Alabdullah, T. T. Y., Ahmed, E. R., and Nor, M. I. (2020). The World Declining Economy And Coronavirus Pandemic: Systems Should Be Continued. Russian Journal of Agricultural and Socio-Economic Sciences 102, 89-96. doi: 10.18551/rjoas.2020-06.11.

Alabdullah, T. T. Y \& Ahmed, E. R. (2020). Audit Committee Impact on Corporate Profitability in Oman Companies: an Auditing and Management Accounting Perspective. Riset Akuntansi dan Keuangan Indonesia, Vol. 5, no. 2, pp. $121-128$

Alabdullah, T. T. Y \& Ahmed, E. R. \& Abushammala, S. (2020). Growth of Companies: Empirical Study of the Companies Listed in Developing Economies. Journal of accounting Science, Vol. 4, no. 2, pp. 1-10.

Alabdullah, T. T. Y., Ahmed, E. R., \& Nor, M. I. (2019). Do board characteristics provide more enhancement for firm financial performance? A corporate governance perspective. New challenges in corporate governance: Theory and practice (pp. 89-91). https://doi.org/10.22495/ncpr_25.

Alabdullah, T. T. Y., Ahmed, E. R., \& Nor, M. I. (2018). New Ideas from Management, Finance and Accounting 
Perspective: The Research for A $_{\text {ond }}$ New Link ${ }_{5}$ Betweegn A Company's Outcome and Risk Management. 5th International Conference on New Ideas in Management, Economics and Accounting.

Alabdullah, T. T. Y. and Ahmed, E. R. (2018). Corporate Governance: To What Extent it is important in the Arab Countries. International Journal of Science and Research 7.

Alabdullah, T. T. Y., Yahya, S., Nor, M. I., \& Majeed, F. Q. (2016). An Investigation of Corporate Governance from A New Perspective: Examining the Financial Performance of Companies and The Impact of Executive Turnover. Corporate Board: Role, Duties \& Composition, 12(1).

Alabdullah, T. T. Y., Yahya, S., \& Ramayah, T. (2014a). Corporate Governance Development: New or Old Concept? European Journal of Business and Management, 6(7), 312-315.

Alabdullah, T. T. Y., Yahya, S., \& Ramayah, T. (2014b). Corporate Governance Mechanisms and Jordanian Companies' Financial Performance. Asian Social Science, 10(22), p247.

Alfadhl, M. M. A., Alabdullah, T. T. Y. (2016). Agency Cost and Management Behavior: The Role of Performance as a Moderator. International Journal of Science and Research (IJSR), 5(1), 1858-1864.

Alfadhl, M. M. A. F., \& Alabdullah, T. T. Y. (2013). Determinants of the Managerial Behavior of Agency Cost and its influential extent on Performance: A study in Iraq. International Journal of Humanities and Social Science, 3(6).

Almashhadani, M. (2020). How Does Corporate Governance Leverage Organizational Performance: A Survey With Suggestions And Notes For Further Research. Russian Journal of Agricultural and SocioEconomic Sciences 3(111)

Almashhadani, M. (2020). Testing the effecting elements of R\&D engineer's inventively in design industrialization Sector: A study in Singapore. Journal of Information and Computational Science, 10(5).

Ali, A., \& Zarowin, P. (1992). The role of earnings levels and annual earnings-returns studies. Journal of Accounting Research, 32(1), 61-74.

Asmild, M., Kronborg, D., Mahbub, T., \& Matthews, K. (2019). The efficiency patterns of Islamic banks during the global financial crisis: The case of Bangladesh. The Quarterly Review of Economics and Finance, 74, 67-74.

Bahoo, S., Ahmed, F., Shoukat, A., \& Ahmad, M. (2019). Impact of Corporate Governance on American Corporates' Financial Performance: The Mediating Role of Derivatives. Journal of Independent Studies \& Research: Management \& Social Sciences \& Economics, 17(1).

Bai, C. E., Liu, Q., Lu, J., Song, F. M., \& Zhang, J. (2004).

Corporate governance and market valuation in China. Journal of Comparative Economics, 32(4), 599- 616.

Bang Dyhrberg, M., \& Langaa Jensen, P. (2004). Organizations in context: proposal for a new theoretical approach in prescriptive accident research. Safety science, 42(10), 961-977.

Brennan, N. M., \& Solomon, J. (2008). Corporate governance, accountability and mechanisms of accountability: an overview. Accounting, Auditing \& Accountability Journal, 21(7), 885-906.

Brickley, J. A., \& Zimmerman, J. L. (2010). Corporate governance myths: comments on Armstrong, Guay, and Weber. Journal of Accounting and Economics, 50(2), 235-245
Bushman, R. M., \& Smith, A. J. (2001). Financial accounting information and corporate governance. Journal of accounting and Economics, 32(1), 237-333.

Cadbury Committee, 1992. Committee on the Financial Aspects of Corporate Governance. Report of the Committee on the Financial Aspects of Corporate Governance London, Gee.

Collins, D., \& Huang, H. (2011). Management entrenchment and the cost of equity capital. Journal of Business Research, 64(4), 356-362.

Crifo, P., Escrig-Olmedo, E., \& Mottis, N. (2019). Corporate governance as a key driver of corporate sustainability in France: The role of board members and investor relations. Journal of Business Ethics, 159(4), 11271146.

De Nicolò, G., Laeven, L., \& Ueda, K. (2008). Corporate governance quality: Trends and real effects. Journal of Financial Intermediation, 17(2), 198-228.

Denis, D. K. (2001). Twenty-five years of corporate governance research and counting. Review of financial economics, 10(3), 191-212.

Essia Ries, A. (2014). Islamic Sukuk: Pricing mechanism and rating [Електронний ресурс]/Essia Ries Ahmed, Md. Aminul Islam, Tariq Tawfeeq Yousif Alabdullah. Journal of Asian Scientific Research, (4), 11.

Farinha, J. (2003). Corporate governance: a survey of the literature. Universidade do Porto Economia Discussion Paper, 11.

Hebble, A., \& Ramaswamy, V. (2005). Corporate Governance And Firm Characteristics (The Sarbanes-Oxley Act Of 2002). Journal of Business \& Economics Research (JBER), 3(5).

Jamel, L., Albogami, H. E., Abdulaal, M. A., \& Aljohani, N. A. (2021). Do agency conflicts between managers and shareholders affect corporate risk management and financial performance of Saudi firms? Journal of Investment Compliance. Vol. 22 No. 1, pp. 58-73.

Jensen, M. C. (2004). The agency costs of overvalued equity and the current state of corporate finance. European Financial Management, 10(4), 549-565.

Jensen, M. C., \& Meckling, W. H. (1976). Theory of the firm: Managerial behavior, agency costs and ownership structure. Journal of financial economics,3(4), 305360.

Kivaya, B. M., Kemboi, A., \& Odunga, R. (2020). Moderating Role Of Firm Size On Corporate Governance And Financial Performance Of Microfinance Institutions In Kenya. African Journal of Emerging Issues, 2(1), 1-23.

Luo, Y. (2005). Corporate governance and accountability in multinational enterprises: Concepts and agenda. Journal of International Management, 11(1), 1-18.

Mensi, W., Tiwari, A. K., \& Yoon, S. M. (2017). Global financial crisis and weak-form efficiency of Islamic sectoral stock markets: An MF-DFA analysis. Physica A: Statistical Mechanics and its Applications, 471, 135-146.

Morck, R., \& Steier, L. (2005). The global history of corporate governance: An introduction. In A history of corporate governance around the world: Family business groups to professional managers (pp. 1-64). University of Chicago Press.

Munir, A., Khan, F. U., Usman, M., \& Khuram, S. (2019). Relationship between corporate sustainability, corporate governance and financial performance. Pakistan Journal of Commerce and Social Sciences (PJCSS), 13(4), 915-933.

Nor, M. I., Masron, T. A., \& Alabdullah, T. T. Y. (2020). Macroeconomic fundamentals and the exchange rate volatility: empirical evidence from Somalia. $S A G E$ Open, 10(1), 2158244019898841. 
Rangkuti, Z. (2020). The effects of Tier-1 capital to risk management and profitability on performance using multiple fixed effect panel data modelol Measulsing 2 Business Excellence.Vol. 25 No. 2, pp. 121-137.

Rechner, P. L., \& Dalton, D. R. (1989). The impact of CEO as board chairperson on corporate performance: evidence vs. rhetoric", The Academy of Management Executive, Vol 3 No. 2, pp.141-143.

Roberts, J., Sanderson, P., Barker, R., \& Hendry, J. (2006). In the mirror of the market: The disciplinary effects of company/fund manager meetings.Accounting, Organizations and Society, 31(3), 277-294.

Russ, R. W., Previts, G. J., \& Coffman, E. N. (2006). The stockholder review committee of the Chesapeake and Ohio Canal Company, 1828-1857: Evidence of changes in financial reporting and corporate governance. The Accounting Historians Journal, 125-143.

Susanti, S., Andhani, M., \& Zulaihati, S. (2019). The Influence of Intellectual Capital and Good Corporate Governance on Financial Performance in Banking Companies. AFEBI Accounting Review, 3(02), 3546.

Widiatmika, P. H., \& Darma, G. S. (2018). Good Corporate Governance, Job Motivation, Organization Culture Which Impact Company Financial Performance. Jurnal Manajemen Bisnis, 15(3), 82-99.

Yermack, D. (1996). Higher market valuation of companies with a small board of directors", Journal of financial economics, Vol. 40 No. 2, pp. 185-211.

Yuka, K. (2010). Theories and Realities of Asian Corporate Governance: From 'Transplantation'to the Asian Best Practices. Procedia-Social and Behavioral Sciences, 2 (5), 6883-6895.

Zheka, V. (2006). Corporate governance and firm performance in Ukraine", Heriot-Watt University Centre for Economic Reform and Transformation Discussion Paper, Vol 5, pp.1

Copyright (C) 2020 and. This is an open-access article distributed under the terms of the Creative Commons Attribution License (CC BY). The use, distribution or reproduction in other forums is permitted, provided the original author(s) and the copy-right owner(s) are credited and that the original publication in this journal is cited, in accordance with accepted academic practice. No use, distribution or reproduction is permitted which does not comply with these terms. 


\section{LIST OF TABLES}

1 Multicollinearity test...

2 R Square of Growth

3 Regression Analysis 
Tariq Tawfeeq Yousif Alabdullah, Essia Ries Ahmed, Mohammed Almashhadani, Sara Kadhim Yousif, Hasan Ahmed

Almashhadani, Raghad Almashhadani, Eskasari Putri

$\underline{\text { TABLE } 1 / \text { Multicollinearity test }}$

\begin{tabular}{|c|c|c|}
\hline Variables & Tolerance Value & VIF \\
\hline Board size & 0.855 & 1.175 \\
\hline Managers independency & 0.892 & 1.046 \\
\hline Risk management & 0.944 & 1.027 \\
\hline Csize & .878 & 1.139 \\
\hline
\end{tabular}


Tariq Tawfeeq Yousif Alabdullah, Essia Ries Ahmed, Mohammed Almashhadani, Sara Kadhim Yousif, Hasan Ahmed

Almashhadani, Raghad Almashhadani, Eskasari Putri

TABLE 2/ R Square of growth 
Tariq Tawfeeq Yousif Alabdullah, Essia Ries Ahmed, Mohammed Almashhadani, Sara Kadhim Yousif, Hasan Ahmed

TABLE 3/ Regression Analysis

$$
\text { Growth }
$$

Stand. Coeff.

Variables

Board size

Managers independency

Risk management
Beta

$-0.917 * * *$

0.027

$-0.018$
Sig.

0.000

0.417

0.318

Csize .012

Sig. ${ }^{*} \mathrm{p}<.10 . .{ }^{* *} \mathrm{p}<.05 \ldots * * * \mathrm{p}<.01$ 